Industrial Health, 1986, 24, 129-138.

\title{
The Body Burden of Chelatable Lead, Zinc and Copper: A Kinetic Study in Metal Workers
}

\author{
Hiroshi AONO and Shunichi ARAKI*
}

\author{
Department of Public Health and Hygiene, \\ Medical College of Oita, Hazama-cho, Oita 879-56, Japan
}

(Received December 27, 1985 and in revised form May 12, 1986)

\begin{abstract}
Recent data indicate that non-chelatable lead is converted to the chelatable form in the $\mathbf{2 4} \mathrm{h}$ following intravenous administration of calcium disodium ethylenediamine tetraacetate (CaEDTA). To refine our previous model of the kinetics of lead mobilization in the light of those data, we simulated the daily mobilization yield of lead, zinc and copper in urine by CaEDTA and the spontaneous urinary excretion of these metals during a 4-day course of intermittent CaEDTA injection as a function of the body burden of the chelatable metal (A), the proportion of the mobilization yield to $A(k)$, the proportion of the spontaneous urinary excretion to $A(\beta)$, and the proportion of the chelatable metal converted from non-chelatable metal during $24 \mathrm{~h}$ following CaEDTA injection (a) to $A(\alpha)$. The values of $A, a, k, \beta$ and $\alpha$ for each metal were calculated as a solution of the functional equation. We estimated that the body burden of chelatable lead ranged from 2.3 to $9.5 \mathrm{mg}$ (mean $5.5 \mathrm{mg}$ ) in ten metal workers, employed on average for 13 years, with the whole blood lead concentrations of 39-64 (mean 49) $\mu \mathrm{g} / \mathrm{d} l$. Similarly, the body burden of chelatable zinc ranged from 0.2 to 16.6 (mean 0.9 ) $\mathrm{g}$; and that of chelatable copper from 36 to 192 (mean 102) $\mu$ g. The body burdens of chelatable lead and zinc thus estimated were significantly correlated with the whole blood lead and zinc concentrations. The $24 \mathrm{~h}$ mobilization yield of each metal in urine following administration of CaEDTA was approximately 39\% of the chelatable body burden for lead, $0.1 \%$ for zinc and $33 \%$ for copper; $24 \mathrm{~h}$ spontaneous urinary excretions were approximately $2.5,0.01$ and $20 \%$ of the body burdens, respectively. An amount of non-chelatable lead corresponding to $21 \%$ of the body burden of chelatable lead was assumed to be converted from the nonchelatable to the chelatable form during the $24 \mathrm{~h}$ after CaEDTA injection; conversion rates for zinc and copper were almost negligible.
\end{abstract}

Key words: Lead-Zinc-Copper-Body burden-Chelatable metal-Non-chelatable metal-Mobilization test-CaEDTA-Man-Kinetic study

\section{INTRODUCTION}

Attempts have been made to quantify body burdens of chelatable metals based

\footnotetext{
* To whom correspondence should be addressed.
} 
on their mobilization yields in urine following intravenous administration of calcium disodium ethylenediamine tetraacetate (CaEDTA). ${ }^{1-3}$ ) Previously, we introduced a simple model to estimate the body burden of chelatable lead in man based on an assumption that non-chelatable lead is converted to chelatable lead in negligibly small quantity during the $24 \mathrm{~h}$ after CaEDTA injection ${ }^{2)}$. The body burden thus estimated in lead workers was extremely small when compared with the body burden of "total" (chelatable and non-chelatable) lead, and was correlated significantly with the whole blood lead concentration. ${ }^{2)}$

Recently, however, we have found in a study in two lead workers that a considerable amount of non-chelatable lead is converted to chelatable lead during the $24 \mathrm{~h}$ after CaEDTA injection. ${ }^{3)}$ Determination of this conversion rate on a group basis is essential for quantification of the body burden, because the conversion rate seriously affects the estimation of the body burden..$^{2,3)}$

In this study, we introduce two new mobilization models, i.e. for lead and for zinc and copper, which are intended to estimate the body burdeñ of chelatable metals and the conversion rates from the non-chelatable to chelatable forms after CaEDTA injection based on the amount of each metal excreted in urine during a 4 day course of intermittent chelation in lead founders. The percentage of the body burden of chelatable metals which are mobilized into the urine by CaEDTA is also estimated.

\section{SUBJECTS AND METHODS}

\section{Subjects}

Ten male metal founders, aged 44-58 yr (mean $51 \mathrm{yr}$ ), were studied. They were employed at a factory for 7-15 (mean 13) years. At the time of examination, their blood lead concentrations were 39-64 (mean 49) $\mu \mathrm{g} / \mathrm{d} l$; plasma zinc concentrations, $75-108$ (mean 92 ) $\mu \mathrm{g} / \mathrm{d} l$; and plasma copper concentrations, $88-136$ (mean 117) $\mu \mathrm{g} / \mathrm{d} l$.

\section{Injection of CaEDTA and collection of urine samples}

The nature of the procedure was fully explained to all subjects, and this study was carried out with their informed consent. After collection of $24 \mathrm{~h}$ urine samples, CaEDTA was injected intravenously into each subject in daily dosage of $20 \mathrm{mg}$ per $\mathrm{kg}$ body weight in $250 \mathrm{ml}$ of $5 \%$ glucose solution for one hour on the first, second and fourth days during a 4 day course of examination. Urinary lead, zinc and copper excretion was measured on the $24 \mathrm{~h}$ urinary samples just before and during the 4 day course. The adequacy of urinary sampling was checked by measurements of urinary creatinine and specific gravity together with notification by the subjects. The subjects did not work during the period of the urinary collection. Venous blood samples were collected just before CaEDTA injection on the first day. Neither albuminuria nor glucosuria was found in any of the subjects 
before or during CaEDTA injection. No subject had ever been known to suffer from renal disease.

\section{Analytical methods}

Whole blood, erythrocyte and urinary lead concentrations were measured by atomic absorption spectrophotometry (Hitachi Polarized Zeeman Atomic Absorption Spectrophotometer 180-80) after wet ashing, chelation by sodium diethyldithiocarbamate and extraction to water-saturated methylisobutylketone; the plasma lead concentration was measured by the method of DeSilva. ${ }^{4)}$ The plasma and urinary zinc concentrations were measured by atomic absorption spectrophotometry after deproteinization by trichloroacetic acid; the erythrocyte zinc concentration was determined by atomic absorption spectrophotometry after wet ashing. The plasma and erythrocyte copper concentrations were measured by flameless atomic absorption spectrophotometry after deproteinization by trichloroacetic acid; the urinary copper concentration was measured by atomic absorption spectrophotometry after wet ashing, chelation by sodium diethyldithiocarbamate and extraction to watersaturated methylisobutylketone. Whole blood zinc and copper concentrations were calculated by plasma and erythrocyte concentrations of each metal and the blood packed cell volume. The coefficients of variation for plasma, erythrocyte and urinary lead, zinc and copper determinations are described in our previous reports. ${ }^{5,6)}$

\section{RESULTS}

\section{The model for lead (toxic metal)}

The two new mobilization models introduced here are based on our previous work..$^{2,3)}$ As were our previous models, these models are based on two assumptions: (1) that the mobilization yield of the metal in urine following CaEDTA administration, together with the spontaneous urinary excretion, is a constant proportion of the body burden of chelatable metal regardless of the size of the chelatable metal burden, and (2) that metals are mobilized into urine during the first $24 \mathrm{~h}$ after CaEDTA injection for the most part. The first assumption has been verified for lead in rabbits ${ }^{1)}$ and partially in lead workers. ${ }^{2)}$ The second assumption has been verified for lead, zinc and copper in our studies in lead workers. ${ }^{5,6)}$

The first model is introduced for those metals whose body burden decreases after termination of excessive exposure, e.g. toxic metals such as lead. The daily mobilization yield of lead in urine following injection of CaEDTA $(\mathrm{MPb})$ and the spontaneous urinary lead excretion $(\mathrm{UPb})$ during a 4-day course of intermittent CaEDTA injection are simulated as a function of the body burden of chelatable lead (A) (Table 1). Additional factors in the equation are the proportion of $\mathrm{MPb}$ to $\mathrm{A}(\mathrm{k})$, the proportion of $\mathrm{UPb}$ to $\mathrm{A}(\beta)$ and the proportion of the chelatable 
Table 1. MPb and UPb values during a course of CaEDTA injection as a function of $A, \mathbf{k}, \boldsymbol{\beta}$ and $\boldsymbol{\alpha}^{*}$

\begin{tabular}{llll}
\hline Day & \multicolumn{1}{c}{ Chelatable lead** $(\mathrm{mg})$} & \multicolumn{1}{c}{$\mathrm{MPb}, \mathrm{UPb}$ and equation number } \\
\hline 0 & & $\mathrm{UPb}(0)=\beta \mathrm{A}$ & $\cdots \cdots(1) \dagger$ \\
$1 \dagger \dagger$ & $\mathrm{A}$ & $\mathrm{MPb}(1)=\mathrm{kA}$ & $\cdots \cdots(2)$ \\
$2 \dagger \dagger$ & $(1-1.03 \mathrm{k}+\alpha) \mathrm{A}$ & $\mathrm{MPb}(2)=\mathrm{k}(1-1.03 \mathrm{k}+\alpha) \mathrm{A}$ & $\cdots \cdots(3)$ \\
3 & $(1-1.03 \mathrm{k}+\alpha)^{2} \mathrm{~A}$ & $\mathrm{UPb}(3)=\beta(1-1.03 \mathrm{k}+\alpha)^{2} \mathrm{~A}$ & $\cdots \cdots(4)$ \\
$4 \dagger \dagger$ & $(1-1.3 \beta+\alpha)(1-1.03 \mathrm{k}+\alpha)^{2} \mathrm{~A}$ & $\mathrm{MPb}(4)=\mathrm{k}(1-1.3 \beta+\alpha)(1-1.03 \mathrm{k}+\alpha)^{2} \mathrm{~A} \cdots \cdots(5)$ \\
\hline
\end{tabular}

* Abbreviations as in text; $1.03 \mathrm{kA}$ and $1.3 \beta \mathrm{A}$ are $24-\mathrm{h}$ total loss of lead after CaEDTA injection and under no CaEDTA injection, respectively (see Ref. 3).

** The body burden at the beginning of the day.

$\dagger$ The body burden at the beginning of the day is nearly equal to that on the next day (A) because the amount is not considered to reduce significantly during the $24 \mathrm{~h}(\beta \ll 1)^{3}{ }^{3}$ it The day of CaEDTA injection.

lead converted from non-chelatable lead during $24 \mathrm{~h}$ after CaEDTA injection (a) to $\mathrm{A}(\alpha)$.

The formulae for calculating the values of $\mathrm{A}, \mathrm{a}, \mathrm{k}, \beta$ and $\alpha$ from measured values of $\mathrm{MPb}$ and $\mathrm{UPb}$ are introduced as follows. In Table 1, dividing Equation 3 by Equation 2, we have

$$
1-1.03 \mathrm{k}+\alpha=\frac{\mathrm{MPb}(2)}{\operatorname{MPb}(1)}
$$

Substituting $\mathrm{MPb}(1)$ for $\mathrm{kA}$ (See Equation 2) and $\mathrm{MPb}(2) / \mathrm{MPb}(1)$ for $1-1.03 \mathrm{k}+\alpha$ (Equation 6) in Equation 5, we have

$$
1-1.3 \beta+\alpha=\frac{\operatorname{MPb}(1) \mathrm{MPb}(4)}{\{\mathrm{MPb}(2)\}^{2}}
$$

Equation 7 minus Equation 6 equals

$$
1.03 \mathrm{k}-1.3 \beta=\frac{\mathrm{MPb}(1) \mathrm{MPb}(4)}{\{\mathrm{MPb}(2)\}^{2}}-\frac{\mathrm{MPb}(2)}{\mathrm{MPb}(1)}
$$

Dividing Equation 1 by Equation 2, we have

$$
\beta=\mathrm{k} \times \frac{\mathrm{UPb}(0)}{\operatorname{MPb}(1)}
$$

Inserting Equation 9 into Equation 8, we have

$$
\mathrm{k}=\frac{\frac{\mathrm{MPb}(1) \mathrm{MPb}(4)}{\{\mathrm{MPb}(2)\}^{2}}-\frac{\mathrm{MPb}(2)}{\mathrm{MPb}(1)}}{1.03-1.3 \times \frac{\mathrm{UPb}(0)}{\mathrm{MPb}(1)}}
$$

Equations 2 and 6 are rearranged into 


$$
\mathrm{A}=\frac{\mathrm{MPb}(1)}{\mathrm{k}}
$$

and

$$
\alpha=\frac{\operatorname{MPb}(2)}{\operatorname{MPb}(1)}+1.03 \mathrm{k}-1
$$

The value of $\mathrm{a}$ is calculated from $\mathrm{A}$ and $\alpha$, i.e.

$$
\mathrm{a}=\alpha \times \mathrm{A}
$$

Therefore, when the value of $\mathrm{k}$ is calculated by inserting the measured values of $\mathrm{UPb}(0), \operatorname{MPb}(1), \operatorname{MPb}(2)$ and $\mathrm{MPb}(4)$ into Equation 10, the values $\beta, \mathrm{A}, \alpha$ and a are calculated by Equations 9, 11, 12 and 13, respectively.

\section{The model for zinc and copper (essential metals)}

The second model is for those metals whose daily output is nearly equal to their daily input, e.g. the essential metals. This model is essentially the same as that for lead with one exception. It is assumed, in this model, that the daily output of metal is totally supplemented by the input from diet and other sources when CaEDTA is not injected. On the other hand, when CaEDTA is injected during the 4-day course of examination, 24-h net loss of the body burden of chelatable metal is assumed to be $0.91 \mathrm{kA}$ and $0.35 \mathrm{kA}$ for zinc and copper, respectively; the remaining amount $(0.09 \mathrm{kA}$ and $0.65 \mathrm{kA}$, respectively) corresponds to the amount spontaneously excreted in urine in each $24 \mathrm{~h}$ period and is, together with the loss from other routes, supplemented by the input from diet and other sources. These coefficients $(0.09$ and 0.65$)$ are calculated by dividing the mean values of spontaneous urinary excretion $(\mathrm{UZn}(0)$ and $\mathrm{UCu}(0))$ by those of the mobilization yield by CaEDTA $(\operatorname{MZn}(1)$ and $\mathrm{MCu}(1))$ (see Tables 4 and 5).

The alterations in MZn and UZn during the course of CaEDTA injection are shown in Table 2. The formulae for calculating the values of $\alpha, \mathrm{k}, \beta$ and $\mathrm{A}$ are as follows :

Table 2. MZn and UZn values during a course of CaEDTA injection as a function of $A, k, \beta$ and $\boldsymbol{a}^{*}$

\begin{tabular}{llll}
\hline Day & Chelatable zinc** $(\mathrm{g})$ & \multicolumn{1}{c}{$\mathrm{MZn}, \mathrm{UZn}$ and equation number } \\
\hline 0 & & $\mathrm{UZn}(0)=\beta \mathrm{A}$ & $\cdots \cdots(1) \dagger$ \\
$1+\dagger$ & $\mathrm{A}$ & $\operatorname{MZn}(1)=\mathrm{kA}$ & $\cdots \cdots(2)$ \\
$2+\dagger$ & $(1-0.91 \mathrm{k}+\alpha) \mathrm{A}$ & $\operatorname{MZn}(2)=\mathrm{k}(1-0.91 \mathrm{k}+\alpha) \mathrm{A}$ & $\cdots \cdots(3)$ \\
3 & $(1-0.91 \mathrm{k}+\alpha)^{2} \mathrm{~A}$ & $\mathrm{UZn}(3)=\beta(1-0.91 \mathrm{k}+\alpha)^{2} \mathrm{~A}$ & $\cdots \cdots(4)$ \\
$4{ }^{+\dagger}$ & $(1+\alpha)(1-0.91 \mathrm{k}+\alpha)^{2} \mathrm{~A}$ & $\operatorname{MZn}(4)=\mathrm{k}(1+\alpha)(1-0.91 \mathrm{k}+\alpha)^{2} \mathrm{~A}$ & $\cdots \cdots(5)$ \\
\hline
\end{tabular}

* Abbreviations and $0.91 \mathrm{kA}$ as in text.

**, $\dagger$ and $\dagger \dagger$ As in Table 1. 


$$
\begin{gathered}
\alpha=\frac{\operatorname{MZn}(4) \mathrm{UZn}(0)}{\operatorname{MZn}(1) \mathrm{UZn}(3)}-1 \\
\mathrm{k}=\frac{1}{0.91}\left\{1+\alpha-\frac{\operatorname{MZn}(2)}{\operatorname{MZn}(1)}\right\} \\
\beta=\mathrm{k} \times \frac{\mathrm{UZn}(0)}{\operatorname{MZn}(1)}
\end{gathered}
$$

and

$$
\mathrm{A}=\frac{\mathrm{MZn}(1)}{\mathrm{k}}
$$

The value of $\alpha$ can be preliminarily calculated by Equation 14 from measured values of $\mathrm{UZn}(0), \operatorname{MZn}(1), \mathrm{UZn}(3)$ and $\mathrm{MZn}(4)$ in each subject. These values show that it is almost negligible: less than 0.0001 in seven subjects, 0.02 in two subjects and 0.06 in one subject. Hence, Equation 15 is simplified into:

$$
\mathrm{k}=\frac{1}{0.91}\left\{1-\frac{\operatorname{MZn}(2)}{\operatorname{MZn}(1)}\right\}
$$

With the value of $\mathrm{k}$ thus determined by the measured values of $\mathrm{MZn}(1)$ and $\operatorname{MZn}(2)$, the values of $\beta$ and $A$ are calculated from Equations 16 and 17, respectively. In this case, therefore, the interval of urine collection is shortened to three days, i.e. $\mathrm{UZn}(0), \operatorname{MZn}(1)$, and $\operatorname{MZn}(2)$.

The alterations in $\mathrm{MCu}$ and $\mathrm{UCu}$ are simulated in the same way. As the values of $\alpha$ for copper are also negligible (less than 0.01 in nine subjects and 0.02 in one subject), the values of $k, \beta$ and $A$ are calculated from $24-h$ urinary excretion of copper for three days as well:

$$
\begin{gathered}
\mathrm{k}=\frac{1}{0.35}\left\{1-\frac{\mathrm{MCu}(2)}{\mathrm{MCu}(1)}\right\} \\
\beta=\mathrm{k} \times \frac{\mathrm{UCu}(0)}{\mathrm{MCu}(1)}
\end{gathered}
$$

and

$$
\mathrm{A}=\frac{\mathrm{MCu}(1)}{\mathrm{k}}
$$

The values of $k, \beta, \alpha, A$ and a estimated

Estimated values of $\mathrm{k}, \beta$ and $\mathrm{A}$ for lead, zinc and copper together with the values of $\alpha$ and a for lead are shown in Tables 3-5. It is estimated that approximately $39 \%$ of the body burden of chelatable lead is mobilized into urine during $24 \mathrm{~h}$ after CaEDTA injection and that an amount of lead corresponding to approximately $21 \%$ of the body burden is converted from non-chelatable to 

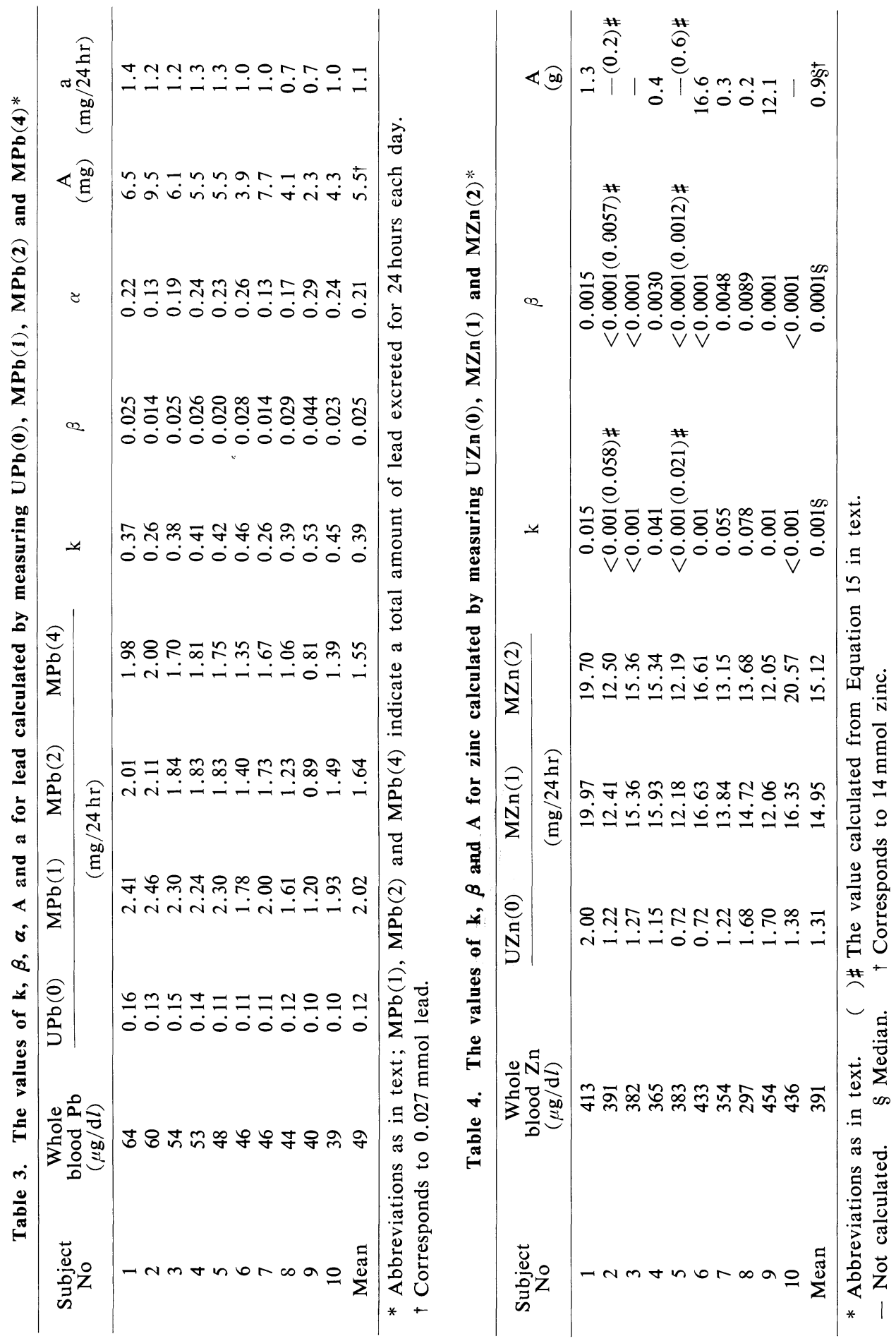
Table 5. The values of $k, \beta$ and $A$ for copper calculated by measuring $\mathrm{UCu}(\mathbf{0})$, $\operatorname{MCu}(1)$ and $\operatorname{MCu}(2) *$

\begin{tabular}{ccccccccr}
\hline $\begin{array}{c}\text { Subject } \\
\text { No }\end{array}$ & $\begin{array}{c}\text { Whole } \\
\text { blood Cu } \\
(\mu \mathrm{g} / \mathrm{d} l)\end{array}$ & \multicolumn{3}{c}{\begin{tabular}{c}
$\mathrm{UCu}(0)$ \\
\cline { 3 - 5 }$(\mu \mathrm{g} / 24 \mathrm{hr})$
\end{tabular}} & $\mathrm{MCu}(1)$ & $\mathrm{MCu}(2)$ & & $\begin{array}{c}\mathrm{A} \\
(\mu \mathrm{g})\end{array}$ \\
\hline 1 & 114 & 19 & 28 & 24 & 0.41 & 0.28 & 68 \\
2 & 123 & 17 & 27 & 24 & 0.32 & 0.20 & 84 \\
3 & 106 & 14 & 24 & 22 & 0.24 & 0.14 & 100 \\
4 & 103 & 10 & 24 & 19 & 0.60 & 0.25 & 40 \\
5 & 122 & 21 & 27 & 25 & 0.21 & 0.16 & 129 \\
6 & 92 & 19 & 20 & 19 & 0.14 & 0.13 & 143 \\
7 & 92 & 17 & 23 & 22 & 0.12 & 0.09 & 192 \\
8 & 125 & 24 & 38 & 34 & 0.30 & 0.19 & 127 \\
9 & 127 & 19 & 24 & 22 & 0.24 & 0.19 & 100 \\
10 & 137 & 14 & 25 & 19 & 0.69 & 0.39 & 36 \\
Mean & 114 & 17 & 26 & 23 & 0.33 & 0.20 & $102 \dagger$ \\
\hline
\end{tabular}

* Abbreviations as in text.

† Corresponds to $1.6 \mu \mathrm{mol}$ copper.
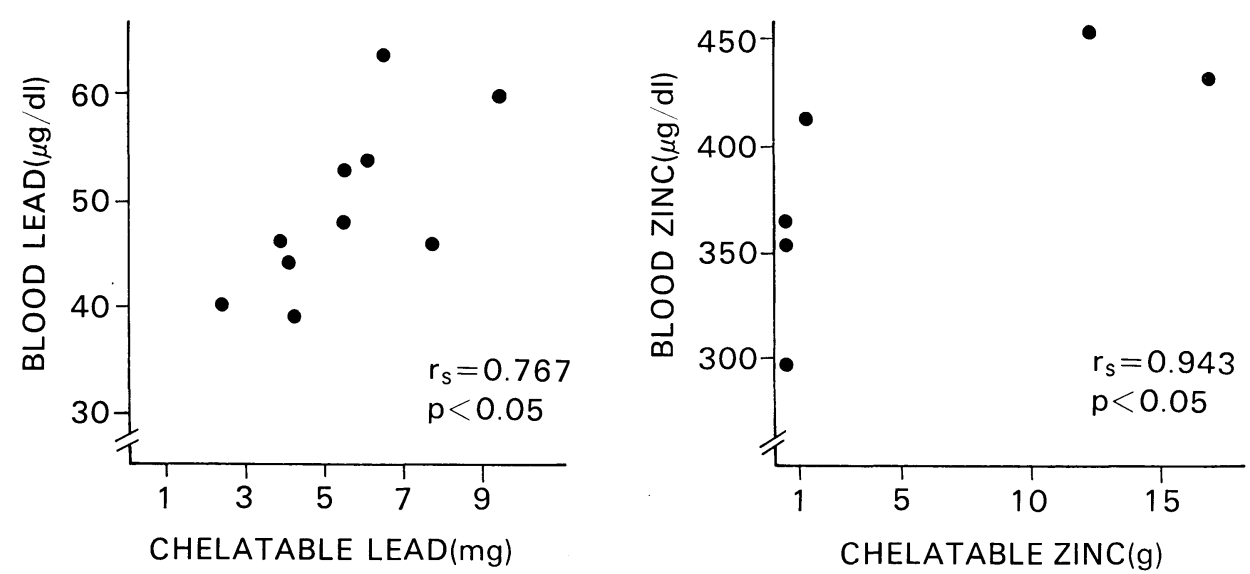

Fig. 1. Relationships between whole blood lead concentration and body burden of chelatable lead, and between whole blood zinc concentration and body burden of chelatable zinc. The $\mathbf{r}_{\mathrm{s}}$ indicates the Spearman's rank correlation coefficient. See Tables 3 and 4 for the subjects examined.

chelatable lead during these $24 \mathrm{~h}$ (Table 3). The body burden of chelatable zinc, on average, is more than a hundred times as large as that of chelatable lead and about ten thousands times as large as that of chelatable copper (Tables 3-5). The value of $\beta$ for copper is more than a half of the $\mathrm{k}$ value; also this $\beta$ value is about ten times as large as that for lead (Tables 3 and 5).

The body burdens of chelatable lead and zinc thus estimated are significantly correlated with the whole blood lead and zinc concentrations, respectively (Fig. 1), but are not correlated with either the plasma or erythrocyte metal concentrations, 
or the spontaneous urinary metal excretion $(p>0.05)$. The body burden of chelatable copper is not correlated with either the whole blood, plasma or erythrocyte copper concentrations, or the spontaneous urinary copper excretion $(p>0.05)$.

\section{DISCUSSION}

The estimated values for the body burden of "chelatable" lead and copper were much smaller than values reported previously for the "total" body burden $(1.69 \mathrm{~g}$ lead in a lead worker and $0.08 \mathrm{~g}$ lead in "healthy" male Japanese; $0.1 \mathrm{~g}$ copper in 70-kg "healthy" man). ${ }^{7-9)}$ Conversely, the body burden of "chelatable" zinc was not extremely small when compared with a reported value for the "total" body burden in 70-kg "healthy" man $(2.3 \mathrm{~g}) .{ }^{9)}$ These estimations suggest that lead and copper in body tissues exist mostly in the non-chelatable form, i.e. firmly bound to compact bone (lead) and to specific proteins such as ceruloplasmin (copper). A great proportion of zinc, on the other hand, is in the chelatable form, i.e. loosely bound to such moieties as plasma albumin.

The dosage of CaEDTA administered to the subjects in this study was 3.21 mmol $(1.2 \mathrm{~g})$ on average. Therefore, the estimated body burdens of chelatable lead $(0.027 \mathrm{mmol}$ or $5.5 \mathrm{mg}$ on average) and of chelatable copper $(0.0015 \mathrm{mmol})$ are greatly exceeded by the amount of CaEDTA injected, while the body burden of chelatable zinc $(14 \mathrm{mmol})$ is not. This factor may explain the large values of $\mathrm{k}$ seen for lead and copper as compared to the extremely small value seen for zinc. These $\mathrm{k}$ values indicate that, on average, only $0.1 \%$ of the body burden of chelatable zinc is mobilized into urine by CaEDTA whereas 39 and $33 \%$ of chelatable lead and copper, respectively, are mobilized during the 24 hours following its administration. The $\mathrm{k}$ value for zinc might increase if a larger dose of CaEDTA were injected.

The $\alpha$ value for lead estimated in the present study, was greater than our previous estimation $(0.02) ;^{3)}$ whereas, the $\mathrm{k}$ minus $\alpha$ value $(0.17)$ was nearly equal to our previous result $(0.14)^{2)}$ under the assumption of $\alpha=0$. The difference in the $\alpha$ value between the two studies might have partly derived from the difference in the length of lead exposure, i.e. 13 and 27 years on average, respectively.

The whole blood lead and zinc concentrations were significantly correlated with the body burden of the chelatable metals thus estimated, while the whole blood copper concentration was not correlated with the body burden of chelatable copper. This finding suggests that the whole blood lead and zinc concentrations are good indicators of the chelatable body burden of those metals.

Finally, the large value of the proportion of the spontaneous urinary excretion of metal to the body burden of chelatable metal ( $\beta$ value) seen for copper suggests that a considerable proportion of chelatable copper is spontaneously excreted in urine even in the absence of CaEDTA injection. There is evidence that copper 
is excreted in urine by a glomerular mechanism in man. ${ }^{10,11)}$

\section{ACKNOWLEDGEMENT}

The mobilization models for lead, zinc and copper in this study were introduced by S. Araki; data collection and analysis were made by $\mathrm{H}$. Aono. We thank Mr. K. Tabuki, Drs. M. Fukahori and K. Murata and Miss S. Yasumi for their technical assistance; Prof. P. J. Landrigan, Mt. Sinai School of Medicine, for his valuable comments. Part of this study was supported by a grant-in-aid from the Ministry of Education, Science and Culture of Japan (Project No. 58770431).

\section{REFERENCES}

1) Teisinger, J., Prerovska, I., Sedivec, V., Flek, J. and Roth, Z. (1969). Attempt on determination of biologically active lead in organism in experimental poisoning, Int. Arch. Gewerbepath. Gewerbehyg., 25, 240.

2) Araki, S. and Ushio, K. (1982). Assessment of the body burden of chelatable lead: a model and its application to lead workers, Br. J. Ind. Med., 39, 157.

3) Araki, S., Murata, K., Yokoyama, K., Aono, H., Yanagihara, S. and Ushio, K. (1983). Conversion rate of non-chelatable to chelatable lead after CaEDTA injection: a kinetic study in two lead workers, J. Appl. Toxicol., 3, 1.

4) DeSilva, P. E. (1981). Determination of lead in plasma and studies on its relationship to lead in erythrocytes, Br. J. Ind. Med., 38, 209.

5) Araki, S., Aono, H., Fukahori, M. and Tabuki, K. (1984). Behavior of lead and zinc in plasma, erythrocytes, and urine and ALAD in erythrocytes following intravenous infusion of CaEDTA in lead worker, Arch. Environ. Health, 39, 363.

6) Aono, H. and Araki, S. (1984). The effects of CaEDTA injection on lead, zinc, copper and ALAD in erythrocyte, plasma and urine in lead-exposed workers: a $24 \mathrm{~h}$ observation, Int. Arch. Occup. Environ. Health, 55, 13.

7) Barry, P.S.I. (1975). A comparison of concentrations of lead in human tissues, Br. J. Ind. Med., 32, 119.

8) Horiguchi, S. and Utsunomiya, T. (1973). An estimate of the body burden of lead in the healthy Japanese population-an attempt to assume absorption and excretion of lead in the healthy Japanese population Part 2, Osaka City Med. J., 19, 1.

9) US National Research Council (1979). Zinc, p. 123, University Park Press, Baltimore.

10) Lifschitz, M. D. and Henkin, R. I. (1971). Circadian variation in copper and zinc in man, J. Appl. Phys., 31, 88.

11) Araki, S., Murata, K., Yokoyama, K., Yanagihara, S., Niinuma, Y., Yamamoto, R. and Ishihara, N. (1983). Circadian rhythms in the urinary excretion of metals and organic substances in "healthy" men, Arch. Environ. Health, 38, 360. 